\title{
Evaluationof Chemical Fungicide for Efficacy Against Leaf Spot of Betel Vine
}

\author{
M.M. Islam ${ }^{1 *}$, M.S. Hossain ${ }^{2}$, A. Hannan ${ }^{3}$, M.M. Rahman ${ }^{4}$, M.M. R. Sarker ${ }^{5}$ \\ ${ }^{I}$ Plant Pathology Division, BARI, Gazipur-1701, Bangladesh \\ ${ }^{2}$ Central Lab, BARI, Gazipur-1701, Bangladesh \\ ${ }^{3}$ Seed Technology Division, BARI, Gazipur-1701, Bangladesh \\ ${ }^{4}$ Plant Pathology Section, HRC,BARI, Gazipur, Bangladesh \\ ${ }^{5}$ On Farm Research Division, BARI, Gazipur, Bangladesh
}

\author{
*Corresponding Author: M.M. Islam, Plant Pathology Division, BARI, Gazipur-1701, Bangladesh
}

\begin{abstract}
Betelvine (Piper betle L.) is an important cash crop of Bangladesh. Leaf spot caused by Phytophthora parasitica var. piperina and or Colletotrichum piparis is the most important disease of the crop. It decreases the production of betevine to a great extent. Management of the disease, the experiment was conducted at Regional Agricultural Research Station (RARS), Rahmatpur, Borishal, Bangladesh during 2016-17, 2017-2018 and 2018-19 cropping seasons. Five fungicide, Autostin (0.1\%), Secure (0.1\%), Dithane M-45(0.1\%), Tilt (0.05\%) and Nativo (0.1\%) were evaluated against the disease. From the results, it was found that Nativo, Tilt and Secure effectively control the leaf spot disease of betelvine. Nativo and Secure were also showed the better performance in decreasing the leaf spot disease of betelvine over control. Same trend of the results of the experiment was observed in case of three consecutive years. In case of three years average of leaf spot disease incidence, Nativo (0.1\%) showed the lowest disease incidence of leaf spot $(9.04$ $\%)$ and the highest disease incidence of leaf spot (52.66\%) was observed in control treatment. The highest three years average yield $3.69 \mathrm{t} / \mathrm{ha}$ of betelvine was found in treatment five i.e Nativo followed by $2.94 \mathrm{t} / \mathrm{ha}$ in the treatment two i.e Secure.
\end{abstract}

Keywords: Fungicide, Leaf spot, Yield, Betelvine.

\section{INTRODUCTION}

Betel vine is a perennial rooted climber which belongs to the family Piperaceae. Its scientific name is Piper betle L. (Srichana et al. 2009). Betel vine having the heart-shaped deep green leaves is an important horticultural crop of aesthetic and commercial values, cultivated under shady areas. It is grown through out the country but, it is commercially cultivated in the vast area of southern parts of Bangladesh. Total area and production of betel leaf in Bangladesh is 23,803.20 hectares and 2,14,252 mtons, respectively in BBS, 2018. The betel leaf contains some vitamins, enzymes, thiamine, riboflavin, tannin, iodine, iron, calcium, minerals, protein and essential oil (Chopra et al. 1956; Kafukur and Kato, 1935). Leaves of betel vine are chewed along with areca nut as a masticator in many parts of the world. Betel chewing is considered to be a good and cheap source of dietary calcium (Jackson, 1973). The betel vine is grown in conservation under shady and humid conditions necessary for the growth of the plant. The shady and moist atmosphere also flavors the development of many diseases, especially leaf spot disease that greatly affects the growth of plants and produce heavy losses to the farmers (Chattopadhya and Maiti, 1990). During cultivation, betel vine is very much affected by diseases and outcome of the farmer is big loss for betel vine cultivation. The most important diseases of betel vine plants are powdery mildew disease, leaf rot disease, foot rot disease and leaf spot disease. It occurs in a very powerful form and if not controlled, causes unlimited damage and even total demoliation of the entire of betel vine plantations (Vijayakumar and Arumugam, 2014). The farmers are also encountered heavy loss in leaf yield every year. The leaf spot is a destructive disease causing substantial yield loss in all the growing area (Samanta,1994). The diseases cause severe damage to natural leaves in the field as well as during transit and unfavourable weather conditions. Betel leaf spot, leaf rot and root rot are serious disease caused by various fungal 
pathogens. These pathogens are necessary to control and damage because betel leaves are one of the most important cash crops in our country. Moreover, the infected leaves of betel vine are sometimes become out of consumption and people are discouraged in it consumption (Patel and Jasrai, 2013). Diseases are the most important problems for betel vine cultivation. Among the diseases of betel vine, leaf rot caused by Phytophthora parasitica var. piperina and leaf spot caused by Colletotrichum piparis is the most devastating disease, which decrease the production of betel vine crop to a great extent. Leaf rot of betel vine caused by Phytophthora parasitica disease is an endemic and cause serious problem all over the betel vine growing areas in Bangladesh (Goswami, et al. 2002; Chowdhury and Ahmed, 1985). Most of the marginal farmers are involved in betel vine cultivation. They grow betel leaf to meet up the national demand as well as to export. For continuous cultivation, the, different disease infestation seem to be alarming for inoculums potential. But recently they are in troubles to grow betel vine due to the leaf spot disease problem. Thus the investigation was urgently necessary to develop the effective control measure for leaf spot disease of betel vine in major growing areas of Bangladesh. However with a view to select the effective fungicide for controlling leaf spot disease of betel vine the present experiment was conducted.

\section{Materials ANd Methods}

The experiment was conducted at Regional Agricultural Research Station (RARS), Rahmatpur, Borishal during three consecutive cropping seasons viz. 2016-2017, 2017-18 and 2018-19. The investication was conducted in five years old betel vine garden established at Regional Agricultural Research Station, Rahmatpur, Borishal. In the garden one betel vine variety namely BARI Pan-1 was planted. Young cuttings of vine of BARI Pan-1 was used as planting materials. The cutting was planted in $3.0 \mathrm{~m} \times 2.0 \mathrm{~m}$ plots maintaining $30 \mathrm{~cm}$ row to row, $10 \mathrm{~cm}$ plant to plant and $1.0 \mathrm{~m}$ plot to plot distance. After establishment of the cutting the field was fertilized with only mustard oil cake at the rate of 6 metric tons per hectare per year. The oil cake was applied into equal installments in the months of May and September. All cultural practices such as weeding, watering, earthing up, pruning, tieing, vine lowering and other operation were done as and when necessary to maintain suitable environment for proper growth of the plants. Shed was provided with a thin roof made of straw and bamboo sticks. Normally farmers of Bangladesh do not use chemical fertilizers in betel vine garden. But, recommended doses of fertilizers viz. MOC $6 \mathrm{t} / \mathrm{ha}$, Urea $180 \mathrm{~kg}$, TSP $150 \mathrm{~kg}$, MoP $36 \mathrm{~kg}$, Zypsum $50 \mathrm{~kg}$ and Zincsulphate $15 \mathrm{~kg}$ per hectare were used in this experiment (Anon. 2012).

The experiment was conducted under natural infection condition in an established orchard. The six treatments including control were used in this experiment viz. $\mathrm{T}_{1}=$ Autostin (Carbendazim) @ 0.1\%, $\mathrm{T}_{2}=$ Secure $600 \mathrm{WG}$ (Fenamidone+ Mancozeb) @ 0.1\%, $\mathrm{T}_{3}=$ Dithane M-45(Mancozeb) @ 0.1\%, $\mathrm{T}_{4}=$ Tilt 250 EC (Propiconazole) @ $0.05 \%, \mathrm{~T}_{5}=$ Nativo 75 WG (Tebuconazole+Trofloxystobin) @ 0.1\%) and $\mathrm{T}_{6}=$ Control with three replications. Three sprays were done at an interval of 7 days while the first one was applied just at the first appearance of the disease symptom. To study the development of leaf spot observations were made in betel vine garden during three consecutive years viz. 2017, 2018 and 2019. Every year all plants of BARI Pan-1 were checked regularly with 10 days interval during January to December to record incidence of leaf spot disease and yield of betel vine. Data were recorded on incidence of leaf spot disease and yield of betel vine. The incidence was expressed as per cent infected leaf and yield was estimated as $\mathrm{t} / \mathrm{ha}$. At the time of data collection, leaf spot infected leaves were collected from the garden and per cent leaf (incidence) was computed based on total number of leaves in each plot on each treatment. Collected data were analyzed statistically following DMRT.

\section{RESULTS}

Results of the experiments of three consecutive years are presented in this chapter chronologically.

\section{- Year 2016-2017}

Effect of five different fungicidal treatments including control on disease incidence of leaf spot and yield of betel vine are presented in the Table 1 . Among the treatments, Nativo $(0.1 \%)$ showed the lowest disease incidence of leaf spot $(9.22 \%)$. The second lowest disease incidence of leaf spot (10.66\%) was found in Tilt preceded by Secure (11.78\%), respectively. The highest disease incidence of leaf spot (51.08\%) was observed in control treatment (Table 1). In case of disease reduction, the highest disease reduction $81.95 \%$ was observed in treatment five followed by $79.13 \%$ in treatment 
four (Table 1). The lowest disease reduction $70.88 \%$ was found in treatment three (Table 1).The maximum yield $3.65 \mathrm{t} / \mathrm{ha}$ was recorded in treatment five i.e Nativo followed by $2.91 \mathrm{t} / \mathrm{ha}$ in treatment two i.e Secure. The lowest yield 1.31t/ha was recorded in control treatment (Table 1).

Table1. Effect of five different fungicide on disease incidence of leaf spot and yield of betel vine in 2016-2017.

\begin{tabular}{|l|l|l|l|l|}
\hline S.No & Treatments & $\begin{array}{l}\text { Disease } \\
\text { incidence }(\%)\end{array}$ & $\begin{array}{l}\text { Disease decreased } \\
\text { over control (\%) }\end{array}$ & $\begin{array}{l}\text { Yield } \\
\text { (t/ha) }\end{array}$ \\
\hline 1 & $\mathrm{~T}_{1}=$ Autostin (Carbendazim) @ 0.1\% & $12.66 \mathrm{c}$ & 75.22 & $2.36 \mathrm{c}$ \\
\hline 2 & $\mathrm{~T}_{2}=$ Secure 600 WG (Fenamidone+ Mancozeb) @ 0.1\%, & $11.78 \mathrm{~d}$ & 76.94 & $2.91 \mathrm{~b}$ \\
\hline 3 & $\mathrm{~T}_{3}=$ Dithane M-45(Mancozeb) @ 0.1\%, & $14.88 \mathrm{~b}$ & 70.88 & $1.82 \mathrm{e}$ \\
\hline 4 & $\mathrm{~T}_{4}=$ Tilt 250 EC (Propiconazole) @ 0.05 \%, & $10.66 \mathrm{e}$ & 79.13 & $2.03 \mathrm{~d}$ \\
\hline 5 & $\mathrm{~T}_{5}=$ Nativo 75 WG (Tebuconazole+Trofloxystobin) @ 0.1\%) & $9.22 \mathrm{f}$ & 81.95 & $3.65 \mathrm{a}$ \\
\hline 6 & $\mathrm{~T}_{6}=$ Control & $51.08 \mathrm{a}$ & - & $1.31 \mathrm{f}$ \\
\hline & \multicolumn{1}{|c}{ \% CV } & 12.88 & - & 6.51 \\
\hline
\end{tabular}

\section{- Year 2017-2018}

Results of the study of the year 2017-2018 are presented in the Table 2. Among the treatments, Nativo $(0.1 \%)$ showed the lowest disease incidence of leaf spot $(8.30 \%)$. The second lowest disease incidence of leaf spot $(9.10 \%)$ was found in Tilt preceded by Secure $(10.62 \%)$, respectively. The highest disease incidence of leaf spot $(52.01 \%)$ was observed in control treatment (Table 2). Considering the disease reduction over control, the highest disease reduction $84.04 \%$ was found in treatment five followed by $82.50 \%$ was found in treatment four. The lowest disease reduction $65.00 \%$ was found in treatment three (Table 2). The maximum yield 3.95 t/ha was recorded in treatment five (Nativo) followed by $3.20 \mathrm{t} / \mathrm{ha}$ in treatment two(Secure). The lowest yield $1.60 \mathrm{t} / \mathrm{ha}$ was recorded in control treatment (Table 2).

Table2. Effect of five different fungicide on disease incidence of leaf spot and yield of betel vine in 2017-2018.

\begin{tabular}{|l|l|l|l|l|}
\hline S.No & Treatments & $\begin{array}{l}\text { Disease } \\
\text { incidence }\end{array}$ & $\begin{array}{l}\text { Disease decreased } \\
\text { over control }(\%)\end{array}$ & $\begin{array}{l}\text { Yield } \\
(\mathbf{t} / \mathbf{h a})\end{array}$ \\
\hline 1 & $\mathrm{~T}_{1}=$ Autostin (Carbendazim) @ 0.1\% & $13.90 \mathrm{c}$ & 73.27 & $2.60 \mathrm{c}$ \\
\hline 2 & $\mathrm{~T}_{2}=$ Secure 600 WG (Fenamidone+ Mancozeb) @ 0.1\%, & $10.62 \mathrm{~d}$ & 79.58 & $3.20 \mathrm{~b}$ \\
\hline 3 & $\mathrm{~T}_{3}=$ Dithane M-45 (Mancozeb) @ 0.1\%, & $18.20 \mathrm{~b}$ & 65.00 & $2.1 \mathrm{e}$ \\
\hline 4 & $\mathrm{~T}_{4}=$ Tilt 250 EC (Propiconazole) @ 0.05\%, & $9.10 \mathrm{e}$ & 82.50 & $2.30 \mathrm{~d}$ \\
\hline 5 & $\mathrm{~T}_{5}=$ Nativo75WG (Tebuconazole+Trifloxystobin) @ 0.1\%) & $8.30 \mathrm{f}$ & 84.04 & $3.95 \mathrm{a}$ \\
\hline 6 & $\mathrm{~T}_{6}=$ Control & $52.01 \mathrm{a}$ & - & $1.60 \mathrm{f}$ \\
\hline & & 11.51 & - & 7.82 \\
\hline
\end{tabular}

\section{- Year 2018-2019}

Results of the year 2018-2019 of this study are presented in Table 3. Among the six treatments, Nativo $(0.1 \%)$ i.e treatment five showed the lowest disease incidence of foot rot $(9.60 \%)$ disease. The second lowest i.e $11.20 \%$ disease incidence of foot rot was found in Tilt and preceeded by $12.55 \%$ in Secure, respectively. The highest disease incidence of foot rot $(54.90 \%)$ was found in control treatment (Table 3). In the point of disease decreased over control, the highest $82.51 \%$ disease was decreased in treatment five followed by $79.60 \%$ decreased in treatment four. In the disease decreased over control. The lowest disease reduction $63.28 \%$ was observed in treatment three (Table 3 ). The maximum yield $3.46 \mathrm{t} / \mathrm{ha}$ was recorded in treatment five (Nativo) followed by $2.70 \mathrm{t} / \mathrm{ha}$ in treatment two (Secure). The lowest yield 1.14 t/ha was recorded in control treatment (Table 3).

Table3. Effect of five different fungicides on disease incidence of leaf spot and yield of betel vine in 2018-19.

\begin{tabular}{|l|l|l|l|l|}
\hline S.No & Treatments & Leaf spot (\%) & $\begin{array}{l}\text { Disease decreased } \\
\text { over control (\%) }\end{array}$ & $\begin{array}{l}\text { Yield } \\
\text { (t/ha) }\end{array}$ \\
\hline 1 & $\mathrm{~T}_{1}=$ Autostin (Carbendazim) @ 0.1\% & $15.85 \mathrm{c}$ & 71.12 & $2.16 \mathrm{c}$ \\
\hline 2 & $\mathrm{~T}_{2}=$ Secure 600 WG (Fenamidone+ Mancozeb) @ 0.1\%, & $12.55 \mathrm{~d}$ & 77.14 & $2.70 \mathrm{~b}$ \\
\hline 3 & $\mathrm{~T}_{3}=$ Dithane M-45 (Mancozeb) @ 0.1\%, & $20.16 \mathrm{~b}$ & 63.28 & $1.63 \mathrm{e}$ \\
\hline 4 & $\mathrm{~T}_{4}=$ Tilt 250 EC (Propiconazole) @ 0.05\%, & $11.20 \mathrm{e}$ & 79.60 & $1.85 \mathrm{~d}$ \\
\hline 5 & $\mathrm{~T}_{5}=$ Nativo75WG (Tebuconazole+Trifloxystobin) @ 0.1\% & $9.60 \mathrm{f}$ & 82.51 & $3.46 \mathrm{a}$ \\
\hline 6 & $\mathrm{~T}_{6}=$ Control & $54.90 \mathrm{a}$ & - & $1.14 \mathrm{f}$ \\
\hline \multicolumn{2}{|c}{ \% CV } & 13.10 & - & 8.80 \\
\hline
\end{tabular}


Average effect of five fungicide on leaf spot and yield of betel vine in three (2016-17, 2017-18 \& 2018-19) consecutive years-

Average results of three consecutive years of the study are presented in the Table 4. Among the six different treatments, Nativo $(0.1 \%)$ showed the lowest disease incidence of leaf spot $(9.04 \%)$. The second lowest disease incidence of leaf spot $(10.32 \%)$ was found in Tilt followed by $11.65 \%$ in Secure $600 \mathrm{WG}$, respectively. The highest disease incidence of leaf spot $(52.66 \%)$ was observed in control treatment (Table 4). In the parameter of disease reduction over control, the highest $82.83 \%$ was measured in treatment five followed by 80.40 was measured in treatment four. The lowest disease reduction $66.29 \%$ was measured in treatment three (Table 4). The maximum average yield $3.69 \mathrm{t} / \mathrm{ha}$ was recorded in treatment five(Nativo) followed by $2.94 \mathrm{t} / \mathrm{ha}$ in treatment two (Secure). The lowest average yield $1.35 \mathrm{t} / \mathrm{ha}$ was recorded in control treatment (Table 4 ).

Table4. Average effect of five fungicide on leaf spot and yield of betel vine in three (2016-17, 2017-18 \& 201819) consecutive years.

\begin{tabular}{|l|l|l|l|l|}
\hline S.No & Treatments & $\begin{array}{l}\text { Disease } \\
\text { incidence }\end{array}$ & $\begin{array}{l}\text { Disease decreased } \\
\text { over control }(\%)\end{array}$ & $\begin{array}{l}\text { Yield } \\
\text { (t/ha) }\end{array}$ \\
\hline 1 & $\mathrm{~T}_{1}=$ Autostin (Carbendazim) @ 0.1\% & $14.13 \mathrm{c}$ & 73.16 & $2.37 \mathrm{c}$ \\
\hline 2 & $\mathrm{~T}_{2}=$ Secure 600 WG (Fenamidone+ Mancozeb) @ 0.1\%, & $11.65 \mathrm{~d}$ & 77.88 & $2.94 \mathrm{~b}$ \\
\hline 3 & $\mathrm{~T}_{3}=$ Dithane M-45 (Mancozeb) @ 0.1\%, & $17.75 \mathrm{~b}$ & 66.29 & $1.85 \mathrm{e}$ \\
\hline 4 & $\mathrm{~T}_{4}=$ Tilt 250 EC (Propiconazole) @ 0.05\%, & $10.32 \mathrm{e}$ & 80.40 & $2.06 \mathrm{~d}$ \\
\hline 5 & $\mathrm{~T}_{5}=$ Nativo75WG (Tebuconazole+Trifloxystobin) @ 0.1\% & $9.04 \mathrm{f}$ & 82.83 & $3.69 \mathrm{a}$ \\
\hline 6 & $\mathrm{~T}_{6}=$ Control & $52.66 \mathrm{a}$ & - & $1.35 \mathrm{f}$ \\
\hline & \multicolumn{1}{|c|}{ \% CV } & 12.50 & - & 7.71 \\
\hline
\end{tabular}

\section{DISCUSSION}

The findings of the present investigation are in agreement with the many findings. Anon. (2013) conducted an experiment to management of betel leaf diseases through mustard oil cake $(0.6 \mathrm{t} / \mathrm{ha})$, neem oil cake (1:1), spraying of Salicyclic Acid (500ppm), Provax $(0.2 \%)$, Cupravit $(0.1 \%)$, Ridomol gold $(0.2 \%)$, Secure $(0.1 \%)$ and Tilt $(0.05 \%)$ under natural field condition. Among the various approaches, Ridomil gold (0.2\%) effectively control the leaf spot disease of betelvine. Anon. (2018) and Anon. (2019) carried out an experiment on management of leaf spot and vine rot diseases of betel plant by Autostin (0.1\%), Secure (0.1\%), Dithane M-45 (0.1\%), Tilt $(0.05 \%)$ and Nativo $(0.1 \%)$ under natural condition in an established orchard. They reported that Nativo, Tilt and Secure effectively control the leaf spot disease of betel plant. The highest yield $3.65 \mathrm{t} / \mathrm{ha}$ was found in treatment five (Nativo) followed by $2.91 \mathrm{t} / \mathrm{ha}$ in the treatment two (Secure). From the present study, it may be concluded that Nativo, Tilt 250EC and Secure were effectively control the leaf spot disease of betelvine which can be used in field level to control the disease.

\section{CONCLUSION}

Autostin, Secure, Dithane M-45, Tilt and Nativo were evaluated against the leaf spot disease of betel vine. Results revealed that Nativo, Tilt and Secure effectively control the leaf spot disease of betelvine. The highest three years average yield $3.69 \mathrm{t} / \mathrm{ha}$ of betelvine was found in treatment five i.e Nativo followed by $2.94 \mathrm{t} / \mathrm{ha}$ in the treatment two i.e Secure. Same trend of the results of the experiment was observed in three consecutive years.

\section{ACKNOWLEDGEMENTS}

The authors thankfully acknowledge Bangladesh Agricultural Research Institute, Gazipur to provide financial support and logistic support. Special thanks to Dr. Firoza Khatun, Chief Scientific Officer and Head Plant Pathology Division, BARI for her fruitful discussions. Thanks go to Chief Scientific Officer, RARS, Rahmatpur, Barishal and concern SA of his Office for their cordial assistance in this researc work.

\section{REFERENCES}

[1] Anonymous. 2012. Fertilizer Recommendation Guide (FRG), Bangladesh Agricultural Research Council, Farmgate, Dhaka. Pp.70-71.

[2] Anonymous. 2013. Annual Report (2012-13). Plant Pathology Division, Bangladesh Agricultural Research Institute (BARI), Gazipur-1701, Bangladesh. pp. 3-4. 
[3] Anonymous. 2018. Annual Report (2017-18). Plant Pathology Division, Bangladesh Agricultural Research Institute (BARI), Gazipur-1701, Bangladesh. pp. 39-40.

[4] Anonymous. 2019. Annual Report (2018-19). Plant Pathology Division, Bangladesh Agricultural Research Institute (BARI), Gazipur-1701, Bangladesh. pp. 33-31.

[5] BBS (Bangladesh Bureau of Statistics). 2018. The Year Book of Agriculture Statistics of Bangladesh. Ministry of Planning Govt. of the Peoples Republic of Bangladesh.P.197.

[6] Chattapadhaya SB and Maiti S. 1990. Diseases of Betelvine and Spices. Indian Council of Agricultural Research, New Delhi. 160p.

[7] Chopra RN, Nayar SL and Chopra IC. 1956. Glossary of Indian Medicinal Plant. Pp.194. CSIR, New Delhi.

[8] Chowdhury S and Ahmed M. 1985. Effect of manuring on the wilt of pan (Piper betle L.). Indian J. Agric. Sci. 16: 290-293.

[9] Goswami BK, Kader KA, Rahman ML, Islam MR and Malaker PK. 2002. Development of leaf spot of betel vine caused by Colletotrichum capsici. Bangladesh J. plant Pathol. 9 (1\&2):3-4.

[10] Jackson ML. 1973. Soil Chemical Analysis. Prentice Hall of India (Pvt), New Delhi, India. pp. 30-35.

[11] Kafukur K and Kato R. 1935. Volatile oil of piperaceae. J. Chem. Soc. (Japan). 56:150-154.

[12] Patel RM and Jasrai YT. 2013. Evaluation of fungitoxic potency of Piper betle L. (Mysore variety). Leaf Extracts Against Eleven Phytopathogenic Fungal Strains. Department of Botany, University School of Sciences, Gujarat University, Ahmedabad - 380009, Gujarat, India.

[13] Samanta C. 1994. A report on the Problems and Solutions of Betel Vine Cultivation. A booklet published by Mr. H.R. Adhikari, C-2/16, Karunamoyee, Salt Lake City, Kolkata -64 (WB), India.

[14] Srichana D, Phumruang A and Chongkid B. 2009. Inhibition effect of betel leaf extraction the growth of Aspergillus flavus anf Fusarium verticillioides. Depertment of Agricultural Technology, Faculty of Science and Technology, Thammasat University, Pathum Thani, Thailand.

[15] Vijayakumar J and Arumugam S. 2014. Oidium piper is fungus identification for Piper betle plants using digital image processing, Department of ECE, Nandha College of Technology, Tamil Nadu, India.

Citation: M.M. Islam, M.S. Hossain, A. Hannan, M.M. Rahman, M.M. R. Sarker, "Evaluationof Chemical Fungicide for Efficacy Against Leaf Spot of Betel Vine. International Journal of Research Studies in Biosciences. 2020; 8(7): 16-20. DOI: https://doi.org/10.20431/2349-0365.0807003.

Copyright: (c) 2020 Authors. This is an open-access article distributed under the terms of the Creative Commons Attribution License, which permits unrestricted use, distribution, and reproduction in any medium, provided the original author and source are credited. 